\title{
Understanding MHC class I presentation of viral antigens by human dendritic cells as a basis for rational design of therapeutic vaccines
}

\author{
Nadine van Montfoort, Evelyn van der Aa and Andrea M. Woltman* \\ Department of Gastroenterology and Hepatology, Erasmus MC University Medical Center Rotterdam, Rotterdam, Netherlands
}

\section{Edited by:}

Marianne Boes, University Medical

Centre Utrecht, Netherlands

\section{Reviewed by:}

Kristen J. Radford, Mater Medical

Research Institute, Australia

Laurence C. Eisenlohr, Thomas

Jefferson University, USA

*Correspondence:

Andrea M. Woltman, Department of Gastroenterology and Hepatology,

Erasmus MC University Medical

Center Rotterdam, Room Na-1006,

P.O. Box 2040, Rotterdam 3000 CA,

Netherlands

e-mail: a.woltman@erasmusmc.nl

\begin{abstract}
Effective viral clearance requires the induction of virus-specific $\mathrm{CD} 8^{+}$cytotoxic $\mathrm{T}$ lymphocytes (CTL). Since dendritic cells (DC) have a central role in initiating and shaping virusspecific CTL responses, it is important to understand how DC initiate virus-specific CTL responses. Some viruses can directly infect DC, which theoretically allow direct presentation of viral antigens to CTL, but many viruses target other cells than DC and thus the host depends on the cross-presentation of viral antigens by DC to activate virus-specific CTL.
\end{abstract}

Research in mouse models has highly enhanced our understanding of the mechanisms underlying cross-presentation and the dendritic cells (DC) subsets involved, however, these results cannot be readily translated toward the role of human DC in MHC class I-antigen presentation of human viruses. Here, we summarize the insights gained in the past 20 years on $\mathrm{MHC}$ class I presentation of viral antigen by human DC and add to the current debate on the capacities of different human DC subsets herein. Furthermore, possible sources of viral antigens and essential DC characteristics for effective induction of virus-specific CTL are evaluated.

We conclude that cross-presentation is not only an efficient mechanism exploited by DC to initiate immunity to viruses that do not infect DC but also to viruses that do infect DC, because cross-presentation has many conceptual advantages and bypasses direct immune modulatory effects of the virus on its infected target cells.

Since knowledge on the mechanism of viral antigen presentation and the preferred DC subsets is crucial for rational vaccine design, the obtained insights are very instrumental for the development of effective anti-viral immunotherapy.

Keywords: virus, human dendritic cell, cross-presentation, CTL priming, MHC class I-antigen presentation, viral immunity, immunotherapy, virus-host interaction

\section{ROLE OF DENDRITIC CELLS IN THE INDUCTION OF ANTI-VIRAL IMMUNITY}

Immune responses to viral infections are a complex interplay between the virus, target cells, and cells of the immune system. Effective viral clearance requires the induction of virus-specific $\mathrm{CD} 8^{+}$cytotoxic $\mathrm{T}$ lymphocytes (CTL), which have the capacity to eradicate the virus by direct and indirect mechanisms (1). DC, a low frequent population of white blood cells play a central role in the induction of virus-specific CTL, since they are the most potent antigen presenting cells and unique for their capacity to activate naïve T cells (2). DC are located at strategic positions at sites of pathogen entry, where they continuously sample the environment for invading pathogens. Capturing antigens in combination with encountering danger signals from pathogens induces maturation of DC and their migration to secondary lymphoid organs where

Abbreviations: DC, dendritic cell; CTL, cytotoxic T lymphocyte; mDC, myeloid dendritic cell; pDC, plasmacytoid dendritic cell; moDC, monocyte-derived dendritic cell; LC, Langerhans cell; PRR, pattern-recognition receptor; VLP, virus-like particle; CLR, C-type lectin receptor; FcR, Fc receptor; TLR, Toll-like receptor. they can activate naïve T cells. Activation of naïve $\mathrm{CD} 8^{+} \mathrm{T}$ cells and polarization toward effective CTL requires presentation of MHC class I-peptide complexes (signal 1) together with co-stimulation (signal 2) and the presence of cytokines (signal 3) such as IL-12 (3) and IFN $\alpha$ (4).

Dendritic cells comprise a family of different subsets, diverging in ontogeny, localization, and phenotype. Each DC subset has its own specialized immune functions with regard to the functional interactions with all kind of immune cells, including $\mathrm{T}$ cells, $\mathrm{B}$ cells, and NK cells, due to differential expression of receptors and intrinsic differences in their ability to produce different cytokines and other membrane-bound and soluble immune modulatory molecules (5). Human DC subsets present in blood, peripheral, and lymphoid tissues can be classified in two main categories: plasmacytoid DC (pDC) and myeloid DC (mDC), which can be further divided into $\mathrm{BDCA}^{+}\left(\mathrm{CD}^{+} \mathrm{c}^{+}\right)$and $\mathrm{BDCA} 3^{+}\left(\mathrm{CD} 141^{+}\right) \mathrm{DC}(6)$. pDC are specialized in the production of high amounts of antiviral type I interferon (IFN; IFN $\alpha / \beta$ ) upon activation (7), whereas $\mathrm{BDCA}^{+} \mathrm{DC}$ are known for their high production of IL-12 and their ability to induce $\mathrm{T}$ cell responses (5). $\mathrm{BDCA}^{+} \mathrm{DC}$, on the 
other hand, can produce high levels of type III IFN (IFN $\lambda$ ) (8), which possess direct anti-viral activity, and induce Th-1 responses (9). In the skin, two additional mDC subsets have been characterized, epidermal Langerhans cells (LC) and dermal interstitial DC (intDC) (10). Since DC represent a very rare population in the human body that hampers isolation of sufficient numbers, in vitro-generated DC differentiated from monocytes (11) or hematopoietic progenitor cells (12) are frequently used for functional studies on human DC.

The notion that DC compared to other antigen presenting cells stand out in their capacity to induce strong virus-specific CTL goes back more than 20 years, when it was reported that human bloodderived DC exposed to HIV-1 or influenza virus could induce proliferation of autologous CTL $(13,14)$. At that time, it was not known whether the efficacy of DC reflected specialized antigen presentation pathways or that other factors were responsible for the efficacy of DC in virus-specific CTL cell induction. At least it was noted that only low numbers of DC were sufficient to induce influenza-specific T cells (14).

Now we know that DC, in addition to their broad expression of pattern-recognition receptors (PRR) and excellent T cell stimulatory capacities, harbor unique specialized antigen presentation pathways, that are of major importance for their central role in the induction of virus-specific immunity; DC can efficiently facilitate MHC class I presentation of endogenously synthesized antigens, a process that is active in all nucleated cells, but also facilitate MHC class I presentation of antigen engulfed from exogenous sources, a process called cross-presentation (15). DC are very efficient in capturing exogenous antigen, because they express a diverse repertoire of receptors and exploit various mechanisms to engulf antigens, including endocytosis, phagocytosis, and pinocytosis. The crosspresentation capacity of DC may be crucial for the induction of virus-specific CTL during infections with viruses that do not infect DC.

Seminal mouse studies have demonstrated the importance of cross-presentation for the generation of virus-specific CTL responses (16-18). In addition, mouse studies have provided important insights into the cell-biological mechanisms underlying cross-presentation by DC $(19,20)$. However, composition of the human DC compartment and susceptibility to viruses differ largely between mice and men. In addition, the mechanism of cross-presentation by human DC is less well-understood. Therefore, research on MHC class I presentation of viral antigens by human DC is of great importance to understand the induction of virus-specific CTL in humans.

The study into antigen presentation of viruses by subsets of human DC ex vivo has been facing several technical challenges, which has hampered the understanding of this process for many viruses. However, some recent technical advancements have become available that empowered this research. For example, the possibility to more efficiently isolate human DC subsets from peripheral blood and other organs and the development of a new generation of protocols to generate human DC subsets in vitro $(21,22)$, as was previously shown for $\mathrm{BDCA}^{+}$monocyte-derived DC (moDC) (11) and CD34 ${ }^{+}$HPC-derived intDC and LC, that resemble $\mathrm{mDC}$ found in mucosal tissues including skin $(12,23)$. These technical advancements have revived the scientific interest in the interactions between viruses and different human DC subsets. Since 2010, a significant body of literature has been published on presentation of viral antigens by different human DC subsets that facilitated this review, which is based for a large part on studies using human DC.

In the present review, the different mechanisms employed by human DC to facilitate MHC class I presentation of viral antigens are discussed. For this purpose, possible sources of viral antigens, essential DC characteristics for optimal MHC class I presentation of viral antigens, and host factors important for virus-specific CTL induction are defined. Furthermore, the roles of the various human DC subsets of human DC in these processes are evaluated. Since knowledge on mechanisms of virus-specific CTL induction by human DC subset is crucial for rational vaccine design, recommendations for development of effective anti-viral immune therapies will be provided based on the insights obtained in this review.

\section{SOURCES OF VIRAL ANTIGEN FOR MHC CLASS I PRESENTATION BY DC}

Virus-infected DC can use endogenously synthesized viral proteins as antigens for presentation in MHC class I, whereas non-infected DC need to actively engulf exogenous viral antigens for crosspresentation. Here, we discuss possible sources of viral antigen obtained from different viruses for MHC class I presentation by human DC.

Human moDC are permissive for quite a number of viruses including measles virus (MV), human cytomegalovirus (HCMV), influenza A virus (IAV), human T-cell lymphotropic virus type 1 (HTLV-1), dengue virus (DV), vaccinia virus (VV), respiratory syncytial virus (RSV), herpes simplex virus (HSV), and human metapneumovirus (hMPV) (24-36). Although moDC can take up $\mathrm{HIV}-1$, they are largely refractory to HIV-1 productive infection (37), whereas, productive infection of peripheral blood-derived $\mathrm{BDCA}^{+}{ }^{+} \mathrm{DC}$ and $\mathrm{pDC}$ has been demonstrated (38). In addition to moDC, RSV also infects $\mathrm{BDCA}^{+}$and $\mathrm{BDCA}^{+}{ }^{+} \mathrm{mDC}(39)$ and $\mathrm{IAV}$ infects $\mathrm{BDCA}^{+} \mathrm{mDC}$, but not $\mathrm{pDC}(40)$. LC are permissive for MV, but only after maturation (25). Although LC can take up HIV-1, they are not permissive for HIV-1 replication and transmission, but rather prevent it by degradation (41). Permissiveness to infection indicates that these viruses not only enter human DC, they also induce a certain level of protein neo-synthesis in DC that ranges from restricted synthesis of early viral proteins (33) to extensive synthesis of multiple viral proteins and secretion of viral progeny (26). Intracellular synthesis of viral antigens by DC suggests that these infected DC may facilitate direct presentation of viral antigens in MHC class I and activation of virus-specific cytotoxic T cells (CTL). MHC class I presentation of viral antigens has been reported for DC infected with IAV, MV, HTLV-1, and HCMV, albeit sometimes with low efficiency (14, 25, 27, 31, 42).

Nevertheless, it has been demonstrated in several independent studies, involving IAV, HIV-1, and MV, that the efficiency of MHC class I-antigen presentation of replication-incompetent virus was at least comparable to replication-competent virus (25, 40, 43-46). These heat-or UV-treated replication-incompetent viruses have lost the capacity to induce synthesis of viral proteins, but still efficiently enter DC to act as exogenous sources of viral antigen. It was estimated that MHC class I presentation 
of replication-incompetent $\mathrm{IAV}$ by $\mathrm{BDCA1}^{+} \mathrm{mDC}$ was 300 times more efficient than MHC class I presentation of replicationcompetent IAV (40). These studies clearly show that, at least for the viruses studied, endogenous synthesis of viral antigens is not required for $\mathrm{MHC}$ class I presentation and that cross-presentation is an efficient mechanism to facilitate MHC class I presentation of viral antigens.

Thus, cross-presentation is not only an efficient mechanism exploited by DC to initiate immunity to viruses that do not infect DC but also contributes to initiation of anti-viral immunity to viruses that do infect DC. In fact, cross-presentation seems a clever way to bypass direct immune modulatory effects of the virus on its infected target cells. For instance, interference with MHC class I presentation is commonly used by herpes viruses to evade immunity [reviewed by Ref. (47)] and is also exploited by IAV, as was elegantly shown by comparing CMV-specific CTL proliferation by $\mathrm{CMV}$-antigen loaded IAV-infected and uninfected $\mathrm{BDCA}^{+}$ mDC (40). In addition, early during HIV infection, part of the DC compartment is depleted, which may contribute to decreased activation of adaptive immunity (48). Virus-induced cell death is also reported for RSV $(34,39)$ and VV (33).

In addition to replication-incompetent viral particles, other sources of exogenous viral antigens for cross-presentation by human DC include virus-like particles (VLP), viral proteins, and virus-infected cells (Figure 1). VLP morphologically and immunologically resemble infectious viral particles because they contain the natural viral envelop proteins, however, they are not infectious, because they do not contain the viral genome. Although some VLP naturally occur in vivo, they are often man-made, being used as safe representatives of viral particles to study virus-host interactions (49) or in the context of vaccine research $(50,51)$. VLP can be efficient sources of exogenous viral antigen for crosspresentation by $\mathrm{DC}$, as was demonstrated for hepatitis $\mathrm{C}$ virus (HCV) VLP (49), human papilloma virus 16 (HPV16) VLP (50), and VLP composed of the coat protein of papaya mosaic virus (PapMV) (51).

Recombinant proteins such as HCV-derived NS3 (52), HIV1-derived Nef (53), HCMV-derived pp65 (9, 54), and hepatitis B virus $(\mathrm{HBV})$-derived hepatitis B surface antigen $(\mathrm{HBsAg})(55,56)$ are sources of exogenous antigens that are often used to study the mechanism of cross-presentation by DC. Nevertheless, the efficiency of cross-presentation of these recombinant proteins is relatively low compared to other sources of viral antigens. Moreover, with the exception of HBsAg, which is secreted by human hepatocytes and can be measured in peripheral blood, most proteins are not naturally occurring as soluble proteins in vivo but are only present in/associated with infected cells.

Cell-associated antigen, i.e., antigen associated to or present in infected target cells, represents another important source of viral antigens that can be encountered by DC. Albert and colleagues contributed the first evidence of this by showing that uptake of apoptotic IAV-infected monocytes by moDC leads to efficient activation of influenza-specific CTL (57). After this study, a compelling number of studies have confirmed that virus-infected target cells can be efficient antigen sources for cross-presentation in many infections. For instance, VV-infected monocytes $(45,58)$, HTLV-1 infected CD4 ${ }^{+}$T cells (31), MV-infected B cell lines (25),

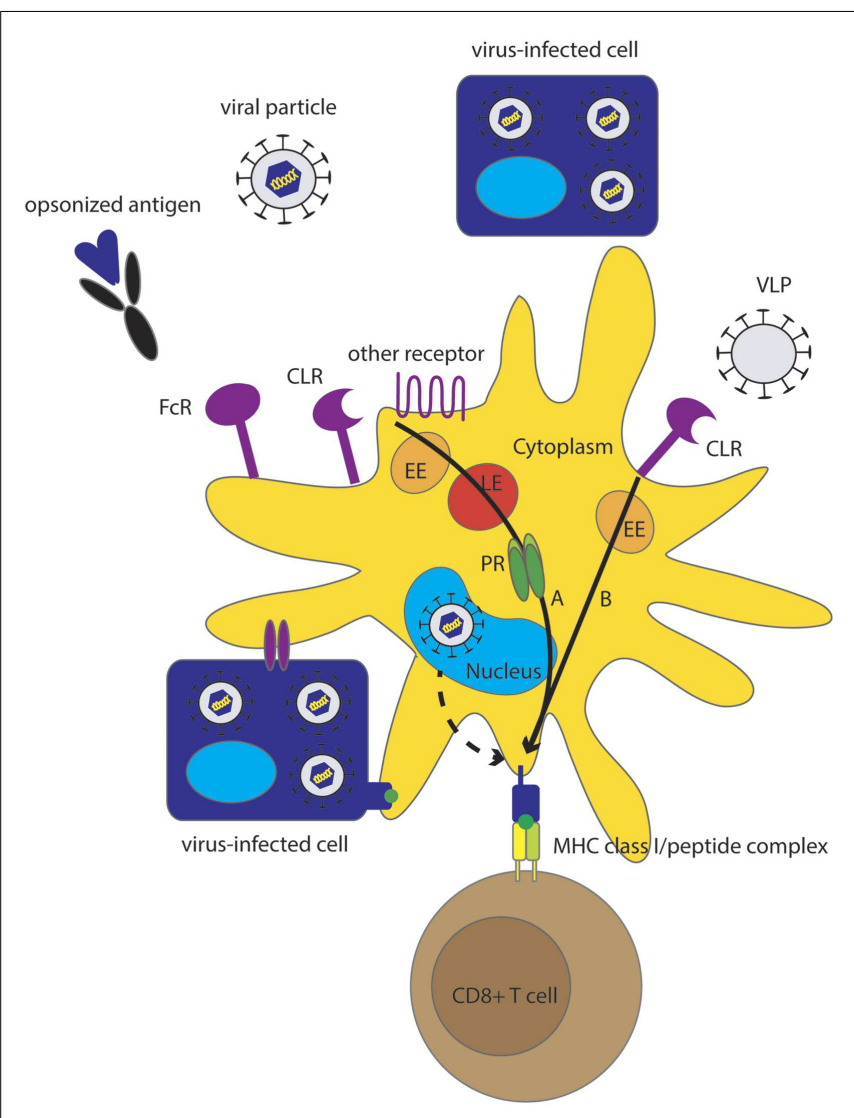

FIGURE 1 | Overview of different pathways underlying MHC class I presentation of viral antigens by human DC. Although direct MHC class I class I presentation may contribute to virus-specific CTL induction (dashed arrow), cross-presentation is an effective mechanism for MHC class I presentation of viruses that do not infect $\mathrm{DC}$ but also for those viruses that do infect DC. Sources of viral antigen that can be efficiently cross-presented by human DC include viral proteins, (infectious) viral particles, VLP, and virus-infected cells, also referred to as cell-associated Ag. Endocytic receptors including CLR, FcR and other receptors (Table 1) play an important role in the uptake of $\mathrm{Ag}$ for cross-presentation.

Cross-presentation can be enhanced by opsonization. Two main pathways for cross-presentation have been described that are also relevant for cross-presentation of viruses by human DC and are characterized by differences in the mechanism of protein degradation and differences in kinetics (black arrows). The slower cytosolic pathway, that relies on proteasomal degradation in the cytosol, is important for cross-presentation of viral particles, infected cells, and opsonized viral proteins (A). The relatively fast vacuolar pathway is independent of proteasomal degradation and is important for cross-presentation of VLP (B). Alternatively, DC can obtain viral peptides or $\mathrm{MHC}$ class I-peptide complexes by interaction with virus-infected cells. EE, early endosome; LE, late endosome; PR, proteasome.

HCMV-infected fibroblasts $(27,59)$, and EBV-transformed B cells $(60,61)$ are reported as efficient sources of viral antigens for crosspresentation by human DC. The latter study nicely illustrated the high efficiency of this mechanism by demonstrating activation of EBV-specific CTL by DC cross-presenting EBV latency antigens that were expressed at low levels in EBV-transformed B cells (61).

In the above-mentioned studies, apoptotic or necrotic viruscontaining cells or cell remnants were used as sources of 
cell-associated antigens for cross-presentation. Transfer of viral peptides from infected cells to DC could represent an alternative efficient mechanism underlying cross-presentation of cellassociated viral antigens. Two different mechanisms facilitating peptide exchange between cells have been described, including transfer of antigenic peptides via intercellular communication channels, called gap junctions (62), and direct transfer of MHC class I/peptide complexes from infected cells to DC, named crossdressing $(63,64)$. The relevance of these pathways in presentation of viral antigens by human DC and induction of virus-specific T-cell immunity should be further evaluated.

In summary, for efficient viral antigen presentation to $\mathrm{CD} 8^{+} \mathrm{T}$ cells, DC can acquire viral antigens from various sources. Although direct presentation of endogenously generated antigen by virusinfected DC has been reported for some viruses, evidence to support an important role for this mechanism in the induction of virus-specific CTL is lacking. In contrast, there is compelling evidence that cross-presentation of exogenously acquired viral antigen is highly efficient and provides an excellent way for the host to bypass evasion mechanisms that several viruses employ to prevent direct MHC class I presentation in infected target cells.

\section{ENDOCYTIC RECEPTORS INVOLVED IN UPTAKE OF VIRUSES BY DC}

Being intracellular parasites, viruses use the host machinery for internalization, proliferation, and transmission. DC are attractive target cells for viral entry because they express numerous receptors at their cell surface and they migrate through the body, which facilitates viral dissemination. Viruses can enter DC via docking with their viral envelop to endocytic receptors expressed at the cell membrane $(43,44,46)$. A commonly described receptor used by viruses to enter DC is DC-specific C-type lectin dendritic cellspecific intercellular adhesion molecule-3-grabbing non-integrin (DC-SIGN/CD209). DC-SIGN is involved in the infection of moDC by DV (32, 65), HCMV (28), HSV (66), MV (67), and IAV (68) and also in DC-mediated transmission of HIV-1 (69) and HTLV-1 (70) to CD4 ${ }^{+}$T cells. DC-SIGN is part of the large family of C-type lectin receptors (CLR), comprising $\mathrm{Ca}^{2+}$-dependent receptors that each have unique functions but share the recognition of carbohydrate structures present on micro-organisms (71). Other CLR family members involved in interaction with viruses include Langerin (CD207), involved in the interaction with MV and HIV-1 (25, 41), DC immunoreceptor (DCIR) (72), proposed as an alternative receptor for $\mathrm{HIV}-1$ promoting infection in cis and trans and macrophage mannose receptor (MMR/CD206), possibly involved in uptake of HBsAg by liver BDCA1 ${ }^{+}$DC (73). Also non-CLR can be involved in the interaction with viruses or VLP. DC-specific heparin sulfate proteoglycan Syndecan-3 cooperates together with DC-SIGN to facilitate infection of DC and transmission to $\mathrm{CD}^{+}{ }^{+} \mathrm{T}$ cells (74) and is involved in the interaction with HPV VLP (75). Since expression of endocytic receptors varies widely between DC subsets (Table 1), the different subsets will likely have specialized roles in the interaction with different viruses, determined by the combination of receptors expressed on each DC subset.

Are these CLRs only involved in supporting viruses to enter the host or did they evolve to support activation of the host's immune system through antigen presentation? Langerin is an important receptor for interaction with pathogens in the skin and has been shown to support antigen presentation in MHC class II, but its role in MHC class I-mediated antigen presentation is under debate (25). Moris et al. showed that blocking of DC-SIGN partly reduced MHC class I presentation of internalized HIV-1 by DC, arguing in favor of a role of DC-SIGN in cross-presentation of HIV-1 (91). In contrast, Sabado et al. showed that blocking of DC-SIGN, DEC-205 (CD205), or MR did not reduce MHC class I presentation of HIV-1 antigens (46) whereas Tjomsland and colleagues showed that blockade of MR even promoted cross-presentation of HIV-1 by DC (92). Thus, the physiological role of DC-SIGN in cross-presentation of HIV-1 is thus far inconclusive, which may be explained by differences in experimental set-up such as the HIV-1 strain used. Antibody-mediated delivery of antigen to the CLRs MR, DEC-205 (82), DCIR (81), DC-SIGN (93), and CLEC9A (94) (Table 1) on human DCs facilitates efficient crosspresentation. These examples show that CLR can facilitate crosspresentation, however, the physiological role of these receptors in cross-presentation of viral antigens is still under debate.

Whereas CLR can directly recognize viral envelop antigens, complement receptors and $\mathrm{Fc}$ receptors $(\mathrm{FcR})$ selectively recognize viral antigens that are opsonized with complement and immunoglobulins, respectively. Antigen immune complexes naturally exist and are formed when pre-existing antibodies bind to blood-borne antigens in the circulation, for example, during HCMV re-infection (85). Binding of immune complexes to Fc $\gamma$ receptor $(\mathrm{Fc} \gamma \mathrm{R})$ on DC leads to efficient cross-presentation in MHC class I (85). Strikingly, the observation that FcR-dependent uptake of HBsAg can enhance activation of HBV-specific CTL was made years before the concept of cross-presentation by DC was recognized (95), indicating that opsonization of viral antigens may be important for generating virus-specific CTL. Similarly, opsonization of antigen by complement can efficiently enhance cross-presentation, as was recently demonstrated for HIV-1 by targeting HIV-1 particles to CR3 (92). In addition, although not classically referred to as opsonization, binding of high-density lipoprotein (HDL) to HCV VLP supported efficient Scavenger receptor B-mediated uptake and cross-presentation (96). A similar role for extracellular heat-shock proteins (HSP) has been proposed [reviewed by Ref. (97)], mainly based on mouse studies in the field of cancer immunotherapy. However, the role of HSP in cross-presentation of viral antigens by human DC remains to be investigated.

Although these results indicate that several endocytic receptors may be involved in facilitating cross-presentation, their exact role needs to be determined. Especially recognition of viral antigens by opsonins seems to be an effective way of natural antigen targeting to DC for cross-presentation. Increased knowledge on the receptors used by viruses for infection on the one hand and the receptors that facilitate cross-presentation on the other hand may be of great value for therapeutic interventions.

\section{MECHANISMS UNDERLYING CROSS-PRESENTATION}

One of the intriguing aspects of cross-presentation is that processing of incoming antigen needs to be very efficient to compete with the vast amount of endogenous proteins for MHC class I binding. 
Table 1 | Summary of receptors that are involved in DC-virus interaction on different DC subsets.

\begin{tabular}{|c|c|c|c|c|c|c|c|c|}
\hline Family & Name & $\begin{array}{l}\mathrm{BDCA1}^{+} \\
\mathrm{mDC}\end{array}$ & $\begin{array}{l}\mathrm{BDCA3}^{+} \\
\mathrm{mDC}\end{array}$ & pDC & $\begin{array}{l}\text { Epidermal } \\
\text { LC }\end{array}$ & $\begin{array}{l}\text { Dermal } \\
\text { intDC }\end{array}$ & moDC & Reference \\
\hline \multirow[t]{6}{*}{ C-type lectin receptors } & DEC-205 (CD205) & + & + & + & - & + & + & MacDonald et al. (76), Ebner et al. (77) \\
\hline & DCIR (CLEC4A) & + & - & + & + & + & + & $\begin{array}{l}\text { Bates et al. (78), Lambotin et al. (79), } \\
\text { Eklöw et al. (80), Klechevsky et al. (81) }\end{array}$ \\
\hline & MMR (CD206) & \pm & + & - & - & + & + & $\begin{array}{l}\text { Chatterjee et al. (82), MacDonald et al. } \\
\text { (76), Lambotin et al. (79) }\end{array}$ \\
\hline & DC-SIGN (CD209) & - & - & - & - & + & + & Turville et al. (83), MacDonald et al. (76) \\
\hline & CLEC9A (DNGR1) & - & + & - & - & - & - & Huysamen et al. (84) \\
\hline & Langerin (CD207) & - & - & - & + & - & - & Turville et al. (83), MacDonald et al. (76) \\
\hline \multirow[t]{10}{*}{ Toll-like receptors } & 1 & + & + & + & + & + & + & $\begin{array}{l}\text { Kadowaki et al. (5), Jongbloed et al. (9), } \\
\text { Lambotin et al. (79) }\end{array}$ \\
\hline & 2 & + & + & - & + & + & + & \\
\hline & 3 & + & + & - & + & + & + & \\
\hline & 4 & + & - & - & - & + & + & \\
\hline & 5 & + & - & - & - & + & + & \\
\hline & 6 & + & + & + & + & + & + & \\
\hline & 7 & - & - & + & + & + & - & \\
\hline & 8 & + & + & - & + & + & + & \\
\hline & 9 & - & - & + & - & - & - & \\
\hline & 10 & + & + & + & - & - & + & \\
\hline \multirow[t]{3}{*}{ Fc $\gamma$ receptors } & $\mathrm{Fc}_{\mathrm{C}} \mathrm{RI}(\mathrm{CD} 64)$ & + & - & $\mathrm{nf}$ & $\mathrm{nf}$ & $\mathrm{nf}$ & \pm & Flinsenberg et al. (85) \\
\hline & Fc $\gamma \mathrm{RIIA}(\mathrm{CD} 32)$ & + & + & + & $\mathrm{nf}$ & $\mathrm{nf}$ & + & Flinsenberg et al. (85), Tel et al. (86) \\
\hline & Fc $\gamma \mathrm{RIII}(\mathrm{CD} 16)$ & - & - & - & $\mathrm{nf}$ & $\mathrm{nf}$ & - & Flinsenberg et al. (85) \\
\hline \multirow[t]{2}{*}{ Complement receptors } & CR4 (CD11c) & + & + & - & + & + & + & MacDonald et al. (76), Lambotin et al. (79) \\
\hline & CR3 (CD11b) & \pm & - & - & \pm & + & + & $\begin{array}{l}\text { Donaghy et al. (87), Lui et al. (88), Poulin } \\
\text { et al. (21) }\end{array}$ \\
\hline Heparan sulfate proteoglycan & Syndecan-3 & nf & $\mathrm{nf}$ & $\mathrm{nf}$ & $\mathrm{nf}$ & $\mathrm{nf}$ & + & de Witte et al. (74) \\
\hline Chemokine receptor & XCR1 & - & + & - & - & - & - & Crozat et al. (89), Bachem et al. (90) \\
\hline
\end{tabular}

pDC, plasmacytoid DC; LC, Langerhans cell; intDC, interstitial DC; moDC, monocyte-derived DC; nf, information not found.

In addition, cross-presentation requires access of incoming antigen to the MHC class I pathway that is mechanistically separated from the uptake vesicles (98).

Dendritic cells harbor unique pathways to facilitate these logistic and mechanistic challenges underlying cross-presentation. Based on research of numerous groups, two main models have been put together for the mechanisms underlying crosspresentation of exogenous antigens, referred to as the "cytosolic" pathway and the "vacuolar" pathway [reviewed by Ref. (20)]. These pathways are not mutually exclusive and may operate together in one cell (99). The most discriminative aspects between the two pathways are discussed below.

In the cytosolic pathway, antigens are degraded by the proteasome, a large enzyme complex situated in the cytosol that makes this pathway sensitive to inhibitors of proteasomal degradation. Alternatively, in the vacuolar pathway, both antigen degradation and MHC class I presentation occur in the endocytic compartment. Involvement of this pathway can be experimentally addressed by confirming resistance to inhibition of proteasomal degradation and sensitivity to inhibition of lysosomal proteolysis.

Lysosomal proteolysis has a detrimental role in the cytosolic cross-presentation pathway. It was experimentally demonstrated that limiting lysosomal proteolysis by chemically increasing the lysosomal $\mathrm{pH}$ favors cross-presentation of viral proteins $\mathrm{HCV}$ derived NS3 and HIV-derived Nef by preventing complete degradation of potential MHC class I binding epitopes (53). Several different adaptations on the endocytic compartment, including a differential lysosomal protease activity, mechanisms to control the lysosomal $\mathrm{pH}$, and antigen storage compartments, together endow DC to facilitate cross-presentation via the cytosolic pathway (100102). Cross-presentation via the cytosolic pathway further requires export of internalized antigens from the endocytic compartment 
to the cytosol for proteasomal degradation, which is probably the rate-limiting step in this pathway, at least for protein antigen. Many enveloped viruses can enter the cytoplasm as part of their infection strategy that requires fusion of the viral envelope with the endosomal membrane to release the viral genome into the cytoplasm. This endosomal fusion capacity probably underlies the efficiency of cross-presentation of viral particles, at least for those particles that are able to enter the cytoplasm of DC. The mechanism of cytosolic delivery for other viral antigens and viruses that do not undergo endosomal fusion in human DC is largely unknown. Candidate proteins that may be involved in cytosolic delivery include HSP and p97 and sec61, which belong to the endoplasmic reticulum-associated protein degradation (ERAD) machinery (20), however, the role of these molecules in human DC is poorly studied.

Interestingly, the cytosolic and vacuolar pathway has totally different kinetics, which can be used to determine which pathway is involved (103). Whereas cross-presentation via the vacuolar pathway is fast and can be detected after $20 \mathrm{~min}$ (104), cross-presentation via the cytosolic pathway is much slower and formation of MHC class I-peptide complexes via this pathway may take at least $8 \mathrm{~h}(100)$, probably because it relies on MHC class I neo-synthesis (20). In contrast, MHC class I loading in the vacuolar pathway occurs in the endocytic compartment and depends on recycling of MHC class I molecules that are constitutively internalized by a highly regulated process (105).

\section{VIRAL ROAD TO CROSS-PRESENTATION}

The cytosolic and the vacuolar pathways were largely established based on model antigens and mouse studies. It is important to assess if these models are applicable to cross-presentation of viral antigens by human DC.

As discussed above, viral particles use receptors expressed on the plasma membrane to enter DC and uptake of viruses often involves endocytosis. After receptor-mediated endocytosis, the cargo is transported through the endocytic compartment, a highly regulated network of vesicles with different characteristics and functions (103). An important function of the endocytic system is to sort internalized receptors and cargo to different locations for either degradation or recycling. Viruses use the endocytic system to exert their fusion capacity, however, at the same time DC use it to obtain viral antigen for cross-presentation. For example, when IAV reaches late endosomes, the low $\mathrm{pH}$ enforces conformational change, leading to hemagglutinin-mediated fusion of the endosomal and viral membranes and release of the viral RNA and proteins into the cytoplasm (106). IAV is efficiently cross-presented, at least when its fusogenic activity is intact $(43,107)$. The fusion dependence was also observed for HIV; cross-presentation of HIV-1 was completely absent when fusion-incompetent HIV-1 mutants were used or fusion was inhibited chemically $(44,46)$. Crosspresentation of HIV-1 viral particles is sensitive to proteasome inhibitors, but enhanced by inhibition of lysosomal proteolysis (46). Taken together, the above-mentioned work suggests a role for the cytosolic pathway in cross-presentation of fusion-competent viral particles, at least by mDC. Interestingly, cross-presentation of IAV by pDC is not sensitive to proteasome inhibitors, but is sensitive to inhibition of endosomal processing. Together with fast MHC class I presentation, this study suggests a role for the vacuolar pathway for cross-presentation of IAV by pDC.

Evidence from different studies involving IAV-infected monocytes (108), HCMV-infected fibroblasts (27), and EBVtransformed B cells (61) suggests that cross-presentation of cellassociated antigen involves uptake by receptor-mediated phagocytosis and that antigen processing is dependent on the proteasome, but also sensitive to inhibition of lysosomal proteolysis (109). Cross-presentation of $\mathrm{Ag}-\mathrm{Ig}$ immune complexes also requires both proteasomal and endosomal antigen processing (85). Taken together, these data indicate that although cross-presentation of both cell-associated antigen and $\mathrm{Ag}-\mathrm{Ig}$ immune complexes require proteasomal degradation, they may need some degree of lysosomal proteolysis to facilitate translocation of antigens from lysosomes to cytoplasm. Since these sources of viral antigen do not have intrinsic fusogenic capacity, they rely on functional specializations of DC to export Ag of the endocytic compartment to the cytosol (103).

Interestingly, several lines of evidence suggest that VLP follow a different pathway for cross-presentation. Cross-presentation of PapMV VLP, HCV VLP, and HBV VLP was not affected by proteasome inhibitors but sensitive to reagents that inhibit lysosomal proteolysis $(51,96,110)$. Furthermore, it was shown that crosspresentation of HBV VLP by both mouse DC (110) and human DC (our own unpublished observations) is fast and TAP-independent. Together, these studies suggest that cross-presentation of VLP occurs via the vacuolar pathway.

The differences in cross-presentation pathways between fusioncompetent viruses and VLP suggest that different vesicles within the endocytic compartment are involved. Chatterjee et al. showed that antigen targeting via MR or DEC-205 both lead to crosspresentation via different compartments (82). Evidence for a process of sorting comes from an elegant study by Lakadamyali et al., where it was shown that after endocytosis, IAV is sorted into a population of dynamic endosomes that rapidly becomes more acidic, which is necessary for the virus to enter the cytoplasm (111). In contrast, an alternative non-viral ligand, transferrin is sorted into a different population of static endosomes that facilitate recycling of antigen and receptors to the cell surface.

Antigen targeting to DC-SIGN can result in trafficking to different cellular compartments, as was shown for HCV envelop protein and Lewis X uptake via DC-SIGN (112). In addition, antibodymediated antigen targeting to the neck region of DC-SIGN was dramatically more efficient with regard to cross-presentation of the targeted antigen compared to targeting to the carbohydratebinding domain, and these differences were related to different endocytic trafficking (93). Taken together, these studies suggest that endocytic sorting is important for the fate of antigens and that sorting occurs at the receptor level. The nature of the sorting signal and the role of endocytic receptors and their adaptor molecules in this process remains to be further elucidated. However, an indication that poly-ubiquitination may be involved in sorting and antigen translocation comes from a mouse study involving the MMR (113).

We conclude that both the cytosolic and the vacuolar pathways are applicable to cross-presentation of viral antigen by human DC, depending on the type of viral antigen that is encountered by DC (Figure 1). The studies discussed above suggest 
that VLP preferentially traffic via the vacuolar pathway for crosspresentation, whereas protein antigen, fusion-competent viral particles, cell-associated antigen, and Ig-opsonized antigen preferentially traffic via the cytosolic pathway for cross-presentation, except in pDC that may preferentially facilitate the vacuolar pathway. Since the above-mentioned studies together suggest that antigen is sorted into pathways with different efficiency of cross-presentation at the receptor level, it is of high importance to gain more knowledge on the receptors used for internalization of viral antigens and their exact role in the sorting of Ag to different pathways in order to fully understand the cross-presentation of viral antigens. Currently, besides VLP, no other viral antigens were found that utilize the vacuolar cross-presentation pathway in human $\mathrm{mDC}$, thus the physiological role of this pathway remains to be further understood. However, since this pathway is highly efficient, as was demonstrated in pDC (114), further understanding of the mechanisms underlying the vacuolar pathway may be of interest for therapeutic purposes.

\section{MATURATION AS A CRITICAL FACTOR FOR CTL INDUCTION}

Antigen presentation in MHC class I can lead to CTL priming or tolerance, depending on the context in which DC encounter the antigen (15). Sensing of danger signals by PRR on DC (Table 1) induce DC maturation, a differentiation process initiated after innate immune recognition that regulates key functions involved in CTL induction, including migration, antigen presentation, costimulation, and production of cytokines. Co-stimulation lowers the threshold for antigen recognition by the T-cell receptor and is important for proliferation, survival, effector function, and memory formation of $\mathrm{T}$ cells. Changes in antigen presentation after DC maturation include upregulation of MHC class I molecules (42), enhanced proteasomal activity (115), and reduced lysosomal antigen degradation (116) due to lower expression of lysosomal proteases (107). It is well-accepted that matured human DC have an enhanced capacity to activate virus-specific CTL (25, 42, 56, 60, 117, 118). Importantly, however, the experimental stimuli used for induction of DC maturation are often not representative for the type of danger signals that are encountered by DC during viral infection in vivo.

Which danger signals can be naturally encountered by PRR on DC during viral infection? Viruses can display danger signals of various nature including viral nucleic acids, replication intermediates, carbohydrate structures, and proteins on the envelop, that can be sensed by PRR on DC (Table 1). IAV and RSV, both ssRNA viruses, induce maturation of different human DC subsets including moDC, $\mathrm{BDCA}^{+}{ }^{+} \mathrm{mDC}$, and $\mathrm{pDC}(34,39,42,119$, 120). Also VLP have been shown to induce DC maturation (49, $50,75)$, which is not dependent on TLR but may be mediated by a recently identified innate recognition mechanism (121). In addition to virus-derived danger signals, virus-induced danger signals produced by the host in response to viral infection can induce DC maturation. Examples of such virus-induced host-derived maturation signals include cytokines such as IFN $\alpha / \beta$ and TNF $\alpha$ secreted by virus-infected cells (122) and damage-associated molecular patterns (DAMP) released by damaged or dying cells (123). During interaction of DC with cell-associated Ag, DC can encounter both virus-derived danger signals and host-derived maturation signals $(27,124,125)$ or host cell-derived DAMP, such as TLR4 ligand high-mobility group box 1 (HMGB1) (126) or CLEC9A ligand F-actin (127).

The induction of DC maturation by virus-derived and virusinduced stimuli suggests that these factors also enhance CTL priming, however, direct experimental evidence on the contribution of virus-induced DC maturation on CTL induction by human DC is limited. IAV-infection of DC is associated with strong DC maturation and efficient antigen-specific CTL proliferation (42, 117). Similarly, TLR agonist poly I:C that mimics viral doublestranded RNA (dsRNA) is a strong inducer of DC maturation and effectively enhances cross-presentation of recombinant viral antigen by several subsets of human DC $(9,56,128,129)$. Also TLR7/8 agonists have been shown to enhance DC-induced CTL expansion and effector function in vitro (81). In contrast, crosspresentation of cell-associated antigen was inhibited when polyI:C or IAV were present in the captured dead cells, suggesting that virus-derived danger signals may also have a detrimental effect on cross-presentation, which may be specific for cross-presentation of cell-associated antigen (130). IFN $\alpha$, a widely studied representative of virus-induced signals, can exert multiple effects on human DC that promote CTL cross-priming [reviewed by Ref. (4)]. For example, moDC differentiated in the presence of IFN $\alpha$, so called IFN $\alpha$-DC, have superior cross-presentation capacity compared to classical moDC $(52,131)$. In conclusion, although it is widely accepted that virus-derived and virus-induced stimulatory signals are required for effective cross-priming of virus-specific CTL, it has been difficult to experimentally address this hypothesis in the currently used in vitro models. Challenges include the low precursor frequency of naïve virus-specific $\mathrm{CD}^{+} \mathrm{T}$ cells and dissection of the separate contributions of DC maturation and antigen presentation to CTL induction.

Interference with DC maturation and thereby subverting the development of effective CTL induction is an important mechanism of immune evasion used by many viruses. Examples of viruses that interfere with DC maturation are MV (132), VV, via the production of cytokine receptor homologs (33), HSV, via destabilization of host mRNA $(35,133)$ and HCMV, which prevents upregulation of co-stimulatory molecules and production of cytokines (134) and induces TGF $\beta$ production by its target cells (124). Furthermore, DC isolated from patients with chronic HIV, $\mathrm{HBV}$, and HCV infections showed functional impairments in the capacity to produce IL-12 or induce T-cell activation, which may be a direct effect of the virus on DC and thereby the cause of the failing adaptive immune response, but could also be the consequence of the chronic infection $(135,136)$.

The connection between innate immune recognition of viruses by human DC and the induction of virus-specific CTL is an important subject for further study. In addition, the PRR and pathways underlying recognition of viruses by DC and the mechanisms by which viruses circumvent these pathways needs to be further explored. Novel molecular techniques such as the ability to knock down PRR in human DC will empower this research, which is important for the development of therapeutic interventions. 


\section{SUBSETS INVOLVED IN CROSS-PRESENTATION OF VIRAL ANTIGEN}

Before 2010, the large majority of studies on cross-presentation of viral antigen by human DC were performed with in vitrogenerated moDC, however, more recently a number of groups have succeeded in obtaining sufficient numbers of DC from blood or other organs to assess the ability and mechanism of crosspresentation of viral antigens by different human DC subsets.

$\mathrm{BDCA}^{+} \mathrm{DC}$ were initially recognized as a subset with superior cross-presentation capacity compared to other human DC subsets $(9,21,89,137)$. Comparison of transcriptional profiles revealed that $\mathrm{BDCA}^{+} \mathrm{DC}$ represent the human equivalent of murine $\mathrm{CD} 8 \alpha^{+}$and $\mathrm{CD}_{103}{ }^{+} \mathrm{DC}(56,138)$, which have a superior intrinsic cross-presentation capacity compared to other DC subsets (139). In parallel, selective expression of CLEC9A (84), a receptor that senses dead cells (140) and facilitates cross-presentation by mouse (141) and human DC (94), suggested that human $\mathrm{BDCA}^{+}$DC would excell in cross-presentation of dead cell material. Superior capacity to cross-present cell-associated antigen by $\mathrm{BDCA}^{+}$DC was demonstrated by several independent studies $(9,21,89,102,137)$, however, not observed in all studies (118). Although $\mathrm{BDCA}^{+}$DC are highly capable of cross-presenting cell-associated antigen, cross-presentation of cell-associated antigen has also been demonstrated for $\mathrm{BDCA1}^{+} \mathrm{DC}(102), \mathrm{pDC}$ $(89,118)$, and moDC $(31,57)$. Also for other types of antigen, cross-presentation is not restricted to the $\mathrm{BDCA}^{+} \mathrm{DC}$ subset. Cross-presentation of protein antigen was shown for peripheral blood and tissue-derived $\mathrm{BDCA1}^{+}$DC $(9,128), \mathrm{BDCA}^{-}{ }^{+}$ pDC $(102,128)$, and $\mathrm{BDCA}^{+} \mathrm{DC}(9,56,102,128,137)$, as well as for in vitro-generated $\mathrm{CD} 34^{+}$-derived DC (102) and moDC, as discussed above. Although $\mathrm{BDCA}^{+}{ }^{+} \mathrm{DC}$ are highly capable of cross-presenting cell-associated antigen, cross-presentation of cell-associated antigen has also been demonstrated for $\mathrm{BDCA}^{+}$ DC (102), pDC (89, 118), and moDC (54).

Both $\mathrm{BDCA}^{+}$and $\mathrm{BDCA}^{+}{ }^{+} \mathrm{DC}$ share the specialized machinery that is associated with efficient cross-presentation capacity, i.e., high phagosomal $\mathrm{pH}$, production of ROS within endocytic compartments, and efficient transfer of exogenous antigens into the cytosol (102). Both subsets have a similar efficiency of endogenous MHC class I presentation after transfection, a similar efficiency of cross-presentation of heat-inactivated IAV that can egress to the cytosol at low $\mathrm{pH}$ and a similar efficiency of cross-presentation of antigen that is selectively delivered to early endosomes (107). Nevertheless, $\mathrm{BDCA}^{+}{ }^{+} \mathrm{DC}$ were superior compared to $\mathrm{BDCA} 1^{+}$ DC at cross-presentation of antigen that was artificially targeted to lysosomes by using antigen conjugated to DEC-205 targeting antibodies (107). This suggests that although both DC subsets can efficiently cross-present Ag delivered to early endosomes, $\mathrm{BDCA}^{+}$ DC may exhibit a specialized machinery to transfer Ag from late endosomes and lysosomes to the cytosol. This DC characteristic might explain the superior capacity to cross-present IgGopsonized antigen targeted to $\mathrm{F} c \gamma \mathrm{R}$ that could not be attributed to superior Fc $\gamma \mathrm{R}$ expression and/or antigen uptake in these cells (85).

Plasmacytoid DC contribute to anti-viral immune responses by producing large amounts of IFN $\alpha / \beta$, however, their role as professional antigen presenting cell in the initiation of virus-specific T-cell responses was initially questioned based on controversial results in mice (86). Direct comparison of intrinsic characteristics that can influence cross-presenting capacity, such as phagosomal $\mathrm{pH}$ and ROS production, between $\mathrm{pDC}$ and $\mathrm{BDCAl}^{+}$and $\mathrm{BDCA}^{+} \mathrm{mDC}$ was hampered due to inconclusive data for $\mathrm{pDC}$ (102). However, pDC express a broad repertoire of antigen-uptake receptors on their cell surface such as FcR and CLR BDCA-2, DEC205, DCIR that can facilitate the uptake and cross-presentation of viral antigens (116) (Table 1). In addition, pDC can efficiently transfer exogenous Ag into the cytosol suggesting that they may be capable of cross-presenting antigen via the cytosolic pathway (102). Numerous functional studies showed that human pDC can cross-present recombinant protein antigens, long peptide antigens, IAV-derived antigens, and cell-associated antigens $(88,118,119$, 142). In addition, it was also demonstrated that pDC can efficiently cross-present viral antigen via the vacuolar pathway, which may be facilitated by MHC class I storage in recycling endosomes (114). Taken together, we conclude that human pDC can efficiently facilitate cross-presentation of a wide range of viral antigens. Direct comparison of cross-presentation efficiency between human pDC and $\mathrm{mDC}$ was thus far inconclusive, with one study showing a higher efficiency of cross-presentation by pDC (114), another study showing superior MHC class I-restricted IAV presentation by $\mathrm{BDCAl}^{+}$mDC (40) and three studies concluding that $\mathrm{pDC}$ and $\mathrm{BDCA}^{+}$or $\mathrm{BDCA}^{+} \mathrm{mDC}$ have similar cross-presentation efficiencies $(118,119,142)$.

Although blood DC required DC maturation for efficient cross-presentation, skin or lymph node DC can cross-present under steady state conditions, which might be due to a more mature/activated status of these tissue DC compared to circulating DC $(56,102,143)$. In addition to $\mathrm{BDCA}^{+}{ }^{+}$and $\mathrm{BDCA}^{+} \mathrm{DC}$, skin contains Langerin ${ }^{+} \mathrm{LC}$ and dermal intDC, often referred to as CD14 ${ }^{+}$DC. Comparison of CD14 ${ }^{+}$DC to other skin DC subsets indicated that this subset showed the least cross-presenting capacity among skin subsets $(10,56)$, which may be related to the finding that these cells express immunoglobulin-like transcript receptors that antagonize CTL development (144). Cross-presentation capacity of LC cells is under debate and may vary upon the source of LC and type of antigen used in experiments. Crosspresentation of recombinant protein antigen by in vitro-generated LC has been demonstrated in several independent studies $(10,102$, 145), however, cross-presentation of replication-incompetent MV and MV-infected cells by skin-derived LC was absent (25). Sine LC are potentially interesting vaccine target cells, because of their presence at mucosal sites such as skin and higher respiratory tract (25), further studies on the cross-presentation capacity of primary LC are required.

We conclude that essential mechanisms of cross-presentation are present among most human DC subsets, with the exception of CD14 ${ }^{+}$DC. Superiority of cross-presentation among DC subsets can be attributed to the repertoire of uptake receptors and adaptations in the endocytic compartment and may vary depending on the type of antigen.

\section{TECHNICAL LIMITATIONS AND NOVEL APPROACHES}

Although several technical advancements have potentiated the study of MHC class I-antigen presentation by human DC, several important questions remain to be addressed. 
One of the current technical challenges is to measure antigen presentation at the level of DC. The purest read-out would be to measure MHC class I-antigen complexes at the surface of DC (signal 1 only), however, tools are lacking (20). The best current available method to quantify MHC class I-antigen presentation is a read-out involving activation or in vitro induction of virus-specific T cells. However, it should be taken into account that activation of virus-specific T cells results from a combination of TCR ligation by MHC class I-peptide complexes (signal 1) and other stimuli provided by DC such as cytokines and co-stimulation (signal 2 and 3 ).

The study of induction of human $\mathrm{CD}^{+} \mathrm{T}$ cells by $\mathrm{DC}$ is also hampered by the extreme low frequency of naïve virus-specific $\mathrm{T}$ cells in peripheral blood. As discussed above, MHC class I presentation by human DC has been most frequently studied for IAV, HIV-1, and CMV. For these viruses, it has been possible to obtain sufficient numbers of "memory" T cells from peripheral blood and use T-cell expansion and IFN $\gamma$ production as read-outs for antigen presentation in an autologous setting $(13,14,54)$. Virus-specific T-cell clones to other viruses can be obtained by several rounds of antigen-specific expansion in vitro. However, performance of such in vitro-generated clones in cross-presentation studies is complicated due to their limited life span and the allogenic bias present in experiments because DC and T cells are not from the same donor. A novel promising approach for the study of cross-presentation of viruses by human DC is the use of T-cell receptor transfer to generate autologous virus-specific T cells $(146,147)$. Such T cells are evaluated in the context of immunotherapy of patients but may also be exploited as tools to monitor antigen presentation by DC.

\section{RECOMMENDATIONS AND CONSIDERATIONS FOR DEVELOPMENT OF THERAPEUTIC VACCINE STRATEGIES}

Chronic viral infections such as HIV, HBV, and HCV are a big health burden and affect 100 millions of patients worldwide. Viral persistence is associated with a failure of the patient's immune response to eradicate the virus (136). In addition to chronic persistent infections, reactivation of latent infections including HCMV, EBV, and HPV is a major threat for immune compromised patients. In addition, a high proportion of these chronic and latent infections including HIV, HBV, HCV, EBV, HPV, and HTLV is related to the development of malignancies later in life (148). Immunotherapy represents an attractive therapeutic intervention to combat such infections and prevent virus-related malignancies by using the body's own defense mechanisms. To accomplish this, immunotherapy is directed to improve virus-specific immunity and eradicate the virus but also generate protective memory responses to prevent re-infections. Moreover, immunotherapy should overcome T-cell exhaustion and anergy, often observed in patients with chronic infections (148).

Insights into the mechanisms underlying effective priming of virus-specific CTL by human DC are instrumental for the development of effective virus-specific immunotherapy. We identified cross-presentation as a crucial mechanism for the induction of virus-specific CTL and embrace the concept to utilize the effective cross-presentation mechanisms naturally present in DC for immunotherapy. In line with this concept, antibodymediated antigen targeting to endocytic receptors is an emerging approach employed by numerous groups to target antigen to DC for cross-presentation. Endocytic receptors that efficiently facilitate cross-presentation by human DC include Fc $\gamma$ RIIA, CLEC9A, DEC-205, and DCIR $(81,85,94,116,149)$. An advantage of antigen targeting to specific receptors is the possibility to select receptors that are uniquely expressed by distinct subsets of DC (Table 1), such as proposed for XCR1 (150) or CLEC9A (94). Selective targeting to DC prevents antigen consumption by irrelevant cells, which may lead to reduced availability of antigen to DC and improper T-cell activation.

As discussed previously, DC maturation is crucial for virusspecific CTL induction. Although the endocytic receptors are very potent in internalizing antigen, their role in promoting DC maturation is less clear. Therefore, the combination of antigen targeting with adjuvants is an important field of study. Fc $\gamma \mathrm{R}$ have been shown to facilitate both efficient antigen uptake and DC maturation, however, it was recently shown that $\mathrm{Fc} \gamma \mathrm{R}$-dependent DC maturation in human DC is less strong than was previously observed in mice DC $(85,151)$. Other interesting approaches that combine antigen targeting to DC and DC maturation in one cargo include TLR-ligand-peptide conjugates (152) and nanoparticles that contain both antigen and adjuvant (116).

Since DC comprise a heterogeneous family of subsets that differ in location, frequency, receptor expression, and functional specializations, it is important to design a therapeutic vaccine with the desired DC subset in mind. Based on accumulated evidence from in vitro studies on antigen presentation by human DC subsets, we conclude that most human DC subsets have the basic capacity to cross-present, as long as the antigen is efficiently targeted to an endocytic compartment that favors cross-presentation. Nevertheless, DC subsets do have unique functional characteristics, such as type of cytokine production, which can have high impact on the type of immune response induced. Moreover, DC subsets express different PRR (Table 1) and only adjuvants for a selected number of TLRs are currently available at clinical grade.

In addition to antigen targeting to DC in vivo, recruiting of DC precursors may represent an attractive immunotherapeutic approach, as was recently proposed for monocytes, which can contain a natural reservoir of HBsAg that can be presented in $\mathrm{MHC}$ class I upon differentiation of these monocytes to moDC (153).

\section{CONCLUDING REMARKS AND FUTURE PERSPECTIVES}

Based on two decades of research into MHC class I-restricted presentation of viral antigen by human DC, we conclude that crosspresentation of viral antigens is a highly efficient mechanism for defense against viruses. Furthermore, cross-presentation of viral antigens seems not only pivotal for defense against viruses that do not infect DC, but also for those that infect DC, as demonstrated by in vitro studies using replication-incompetent IAV, HIV-1, and MV. Since these viruses represent a selection of all viruses that can productively infect human DC, the contribution of direct presentation by human DC infected with other viruses cannot be completely ruled out. Nevertheless, as discussed in this review, cross-presentation has many conceptual advances compared to direct presentation by infected DC.

So far, knowledge on the presentation of viral antigens by human DC is mainly derived from in vitro studies. Whether these studies faithfully represent the in vivo situation is of course difficult 
to predict. Several caveats from these in vitro studies include the use of in vitro-generated DC, which may behave differently than their in vivo counterparts, the use of laboratory adapted virus strains, and pseudo-typed viruses, which may have tropisms that may not represent the in vivo situation, and the use of recombinant viral proteins and TLR ligands that are not fully representative for antigens or danger signals that can be encountered in vivo. Nevertheless, taking these limitations into account, together these studies have given us an important understanding of the mechanisms underlying MHC class I presentation of viral antigens by human DC. This knowledge is an important basis for the rational design of therapeutic vaccines for chronic viral infections.

Interesting venues for further research include identification of DC receptors involved in viral infection and initiation of immune response, elucidation of the molecular signals underlying sorting of viral antigen to endocytic compartments that favor cross-presentation and the role of virus-derived danger signals and virus-induced maturation stimuli in cross-presentation and CTL priming.

A more detailed knowledge of these key factors in virus-host interaction will further empower the design of novel therapeutics for infectious diseases.

\section{ACKNOWLEDGMENTS}

This study was supported by a VIDI grant (project 91712329) from the Netherlands Organisation for Scientific Research (NWO) to Andrea M. Woltman.

\section{REFERENCES}

1. Demers KR, Reuter MA, Betts MR. CD8(+) T-cell effector function and transcriptional regulation during HIV pathogenesis. Immunol Rev (2013) 254:190-206. doi:10.1111/imr.12069

2. Banchereau J, Briere F, Caux C, Davoust J, Lebecque S, Liu YJ, et al. Immunobiology of dendritic cells. Annu Rev Immunol (2000) 18:767-811. doi:10.1146/ annurev.immunol.18.1.767

3. Kalinski P, Hilkens CM, Wierenga EA, Kapsenberg ML. T-cell priming by type1 and type-2 polarized dendritic cells: the concept of a third signal. Immunol Today (1999) 20:561-7. doi:10.1016/S0167-5699(99)01547-9

4. Schiavoni G, Mattei F, Gabriele L. Type I interferons as stimulators of DCmediated cross-priming: impact on anti-tumor response. Front Immunol (2013) 4:483. doi:10.3389/fimmu.2013.00483

5. Kadowaki N, Ho S, Antonenko S, Malefyt RW, Kastelein RA, Bazan F, et al. Subsets of human dendritic cell precursors express different toll-like receptors and respond to different microbial antigens. J Exp Med (2001) 194:863-9. doi:10.1084/jem.194.6.863

6. Dzionek A, Fuchs A, Schmidt P, Cremer S, Zysk M, Miltenyi S, et al. BDCA-2, BDCA-3, and BDCA-4: three markers for distinct subsets of dendritic cells in human peripheral blood. J Immunol (2000) 165:6037-46.

7. Gilliet M, Cao W, Liu Y-J. Plasmacytoid dendritic cells: sensing nucleic acids in viral infection and autoimmune diseases. Nat Rev Immunol (2008) 8:594-606. doi:10.1038/nri2358

8. Lauterbach H, Bathke B, Gilles S, Traidl-Hoffmann C, Luber CA, Fejer G, et al. Mouse CD8alpha+ DCs and human BDCA3+ DCs are major producers of IFN-lambda in response to poly IC. J Exp Med (2010) 207:2703-17. doi:10.1084/jem.20092720

9. Jongbloed SL, Kassianos AJ, McDonald KJ, Clark GJ, Ju X, Angel CE, et al. Human CD141+ (BDCA-3)+ dendritic cells (DCs) represent a unique myeloid DC subset that cross-presents necrotic cell antigens. J Exp Med (2010) 207:1247-60. doi:10.1084/jem.20092140

10. Klechevsky E, Morita R, Liu M, Cao Y, Thompson-snipes L, Briere F, et al. Functional specializations of human epidermal Langerhans cells and CD14+ dermal dendritic cells. Immunity (2008) 29:497-510. doi:10.1016/j.immuni. 2008.07.013
11. Sallusto F, Lanzavecchia A. Efficient presentation of soluble antigen by cultured human dendritic cells is maintained by granulocyte/macrophage colony-stimulating factor plus interleukin 4 and downregulated by tumor necrosis factor alpha. J Exp Med (1994) 179:1109-18. doi:10.1084/jem.179. 4.1109

12. Caux C, Massacrier C, Dezutter-Dambuyant C, Vanbervliet B, Jacquet C, Schmitt D, et al. Human dendritic Langerhans cells generated in vitro from $\mathrm{CD} 34+$ progenitors can prime naive $\mathrm{CD} 4+\mathrm{T}$ cells and process soluble antigen. J Immunol (1995) 155:5427-35.

13. Macatonia SE, Patterson S, Knight SC. Primary proliferative and cytotoxic Tcell responses to HIV induced in vitro by human dendritic cells. Immunology (1991) 74:399-406.

14. Bhardwaj N, Bender A, Gonzalez N, Bui LK, Garrett MC, Steinman RM. Influenza virus-infected dendritic cells stimulate strong proliferative and cytolytic responses from human CD8+ T cells. J Clin Invest (1994) 94:797-807. doi:10.1172/JCI117399

15. Kurts C, Robinson BWS, Knolle PA. Cross-priming in health and disease. Nat Rev Immunol (2010) 10:403-14. doi:10.1038/nri2780

16. Sigal LJ, Crotty S, Andino R, Rock KL. Cytotoxic T-cell immunity to virusinfected non-haematopoietic cells requires presentation of exogenous antigen. Nature (1999) 398:77-80. doi:10.1038/18038

17. Snyder CM, Allan JE, Bonnett EL, Doom CM, Hill AB. Cross-presentation of a spread-defective MCMV is sufficient to prime the majority of virusspecific CD8+ T cells. PLoS One (2010) 5:e9681. doi:10.1371/journal.pone. 0009681

18. Busche A, Jirmo AC, Welten SPM, Zischke J, Noack J, Constabel H, et al. Priming of CD8+ T cells against cytomegalovirus-encoded antigens is dominated by cross-presentation. J Immunol (2013) 190:2767-77. doi:10.4049/jimmunol. 1200966

19. Burgdorf S, Kurts C. Endocytosis mechanisms and the cell biology of antigen presentation. Curr Opin Immunol (2008) 20:89-95. doi:10.1016/j.coi. 2007.12.002

20. Joffre OP, Segura E, Savina A, Amigorena S. Cross-presentation by dendritic cells. Nat Rev Immunol (2012) 12:557-69. doi:10.1038/nri3254

21. Poulin LF, Salio M, Griessinger E, Anjos-Afonso F, Craciun L, Chen J-L, et al. Characterization of human DNGR-1+ BDCA3+ leukocytes as putative equivalents of mouse CD8alpha+ dendritic cells. J Exp Med (2010) 207:1261-71. doi:10.1084/jem.20092618

22. Thordardottir S, Hangalapura BN, Hutten T, Cossu M, Spanholtz J, Schaap $\mathrm{N}$, et al. The aryl hydrocarbon receptor antagonist stemregenin 1 promotes human plasmacytoid and myeloid dendritic cell development from CD34(+) hematopoietic progenitor cells. Stem Cells Dev (2014). doi:10.1089/scd.2013. 0521

23. Van de Laar L, Coffer PJ, Woltman AM. Regulation of dendritic cell development by GM-CSF: molecular control and implications for immune homeostasis and therapy. Blood (2012) 119:3383-93. doi:10.1182/blood-2011-11370130

24. Fugier-Vivier I, Servet-delprat C, Rivailler P, Rissoan M-C, Liu Y-J, RabourdinCombe C. Measles virus suppresses cell-mediated immunity by interfering with the survival and functions of dendritic and T cells. J Exp Med (1997) 186:813-23. doi:10.1084/jem.186.6.813

25. van der Vlist M, de Witte L, De Vries RD, Litjens M, de Jong MAWP, Fluitsma D, et al. Human Langerhans cells capture measles virus through Langerin and present viral antigens to CD4+ T cells but are incapable of cross-presentation. Eur J Immunol (2011) 41:2619-31. doi:10.1002/eji.201041305

26. Riegler S, Hebart H, Einsele H, Brossart P, Jahn G, Sinzger C. Monocytederived dendritic cells are permissive to the complete replicative cycle of human cytomegalovirus. J Gen Virol (2000) 81:393-9.

27. Tabi Z, Moutaftsi M, Borysiewicz LK. Human cytomegalovirus pp65- and immediate early 1 antigen-specific HLA class I-restricted cytotoxic T cell responses induced by cross-presentation of viral antigens. J Immunol (2001) 166:5695-703.

28. Halary F, Amara A, Lortat-Jacob H, Messerle M, Delaunay T, Houles C, et al. Human cytomegalovirus binding to DC-SIGN is required for dendritic cell infection and target cell transinfection. Immunity (2002) 17:653-64. doi:10.1016/S1074-7613(02)00447-8

29. Bender A, Albert M, Reddy A, Feldman M, Sauter B, Kaplan G, et al. The distinctive features of influenza virus infection of dendritic cells. Immunobiology (1998) 198:552-67. doi:10.1016/S0171-2985(98)80078-8 
30. Jones KS, Petrow-Sadowski C, Huang YK, Bertolette DC, Ruscetti FW. Cell-free HTLV-1 infects dendritic cells leading to transmission and transformation of CD4(+) T cells. Nat Med (2008) 14:429-36. doi:10.1038/nm1745

31. Manuel L, Schell TD, Acheampong E, Rahman S, Manuel SL. Presentation of human T cell leukemia virus type 1 (HTLV-1) Tax protein by dendritic cells: the underlying mechanism of HTLV-1-associated neuroinflammatory disease. J Leukoc Biol (2009) 86:1205-16. doi:10.1189/jlb.0309172

32. Tassaneetrithep B, Burgess TH, Granelli-piperno A, Trumpfheller C, Finke J, Sun W, et al. DC-SIGN (CD209) mediates dengue virus infection of human dendritic cells. J Exp Med (2003) 197:823-9. doi:10.1084/jem.20021840

33. Engelmayer J, Larsson M, Subklewe M, Chahroudi A, Cox WI, Steinman RM, et al. Vaccinia virus inhibits the maturation of human dendritic cells: a novel mechanism of immune evasion. J Immunol (1999) 163:6762-8.

34. de Graaff PMA, de Jong EC, van Capel TM, van Dijk MEA, Roholl PJM, Boes J, et al. Respiratory syncytial virus infection of monocyte-derived dendritic cells decreases their capacity to activate CD4 T cells. J Immunol (2005) 175:5904-11.

35. Salio M, Cella M, Suter M, Lanzavecchia A. Inhibition of dendritic cell maturation by herpes simplex virus. Eur J Immunol (1999) 29:3245-53. doi:10.1002/ (SICI) 1521-4141(199910)29:10<3245::AID-IMMU3245>3.0.CO;2-X

36. Tan MC, Battini L, Tuyama AC, Macip S, Melendi GA, Horga M-A, et al. Characterization of human metapneumovirus infection of myeloid dendritic cells. Virology (2007) 357:1-9. doi:10.1016/j.virol.2006.08.004

37. St Gelais C, de Silva S, Amie SM, Coleman CM, Hoy H, Hollenbaugh JA, et al. SAMHD1 restricts HIV-1 infection in dendritic cells (DCs) by dNTP depletion, but its expression in DCs and primary CD4+ T-lymphocytes cannot be upregulated by interferons. Retrovirology (2012) 9:105. doi:10.1186/1742-4690-9-105

38. Smed-Sörensen A, Loré K, Vasudevan J, Louder MK, Andersson J, Mascola JR, et al. Differential susceptibility to human immunodeficiency virus type 1 infection of myeloid and plasmacytoid dendritic cells. J Virol (2005) 79:8861-9. doi:10.1128/JVI.79.14.8861-8869.2005

39. Gupta MR, Kolli D, Garofalo RP. Differential response of BDCA-1 + and BDCA$3+$ myeloid dendritic cells to respiratory syncytial virus infection. Respir Res (2013) 14:1. doi:10.1186/1465-9921-14-71

40. Smed-Sörensen A, Chalouni C, Chatterjee B, Cohn L, Blattmann P, Nakamura $\mathrm{N}$, et al. Influenza A virus infection of human primary dendritic cells impairs their ability to cross-present antigen to CD8 T cells. PLoS Pathog (2012) 8:e1002572. doi:10.1371/journal.ppat.1002572

41. de Witte L, Nabatov A, Pion M, Fluitsma D, de Jong MAWP, de Gruijl T, et al. Langerin is a natural barrier to HIV-1 transmission by Langerhans cells. Nat Med (2007) 13:367-71. doi:10.1038/nm1541

42. Cella M, Salio M, Sakakibara Y, Langen H, Julkunen I, Lanzavecchia A. Maturation, activation, and protection of dendritic cells induced by double-stranded RNA. J Exp Med (1999) 189:821-829. doi:10.1084/jem.189.5.821

43. Bender A, Bui LK, Feldman MAX, Larsson M, Bhardwaj N. Inactivated influenza virus, when presented on dendritic cells, elicits human CD8+ cytolytic T cell responses. J Exp Med (1995) 182:1663-71. doi:10.1084/jem. 182.6.1663

44. Buseyne F, Le Gall S, Boccaccio C, Abastado J-P, Lifson JD, Arthur LO, et al. MHC-I - restricted presentation of HIV-1 virion antigens without viral replication. Nat Med (2001) 7:344-9. doi:10.1038/85493

45. Larsson M, Fonteneau J, Lirvall M, Haslett P, Lifson JD, Bhardwaj N. Activation of HIV-1 specific CD4 and CD8 T cells by human dendritic cells: roles for cross-presentation and non-infectious HIV-1 virus. AIDS (2002) 16:1319-29. doi:10.1097/00002030-200207050-00003

46. Sabado RL, Babcock E, Kavanagh DG, Tjomsland V, Walker BD, Lifson JD, et al. Pathways utilized by dendritic cells for binding, uptake, processing and presentation of antigens derived from HIV-1. Eur J Immunol (2007) 37:1752-63. doi:10.1002/eji.200636981

47. Hansen TH, Bouvier M. MHC class I antigen presentation: learning from viral evasion strategies. Nat Rev Immunol (2009) 9:503-13. doi:10.1038/nri2575

48. Sabado RL, O’Brien M, Subedi A, Qin L, Hu N, Taylor E, et al. Evidence of dysregulation of dendritic cells in primary HIV infection. Blood (2010) 116:3839-52. doi:10.1182/blood-2010-03-273763

49. Barth H, Ulsenheimer A, Pape GR, Diepolder HM, Hoffmann M, Thimme R, et al. Uptake and presentation of hepatitis $\mathrm{C}$ virus - like particles by human dendritic cells. Blood (2005) 105:3605-14. doi:10.1182/blood-2004-05-1952

50. Rudolf MP, Fausch SC, Da Silva DM, Kast WM. Human dendritic cells are activated by chimeric human papillomavirus type- 16 virus-like particles and induce epitope-specific human T cell responses in vitro. J Immunol (2001) 166:5917-24.

51. Leclerc D, Beauseigle D, Denis J, Morin H, Paré C, Lamarre A, et al. Proteasomeindependent major histocompatibility complex class I cross-presentation mediated by papaya mosaic virus-like particles leads to expansion of specific human T cells. J Virol (2007) 81:1319. doi:10.1128/JVI.01720-06

52. Spadaro F, Lapenta C, Donati S, Abalsamo L, Barnaba V, Belardelli F, et al. IFN$\alpha$ enhances cross-presentation in human dendritic cells by modulating antigen survival, endocytic routing, and processing. Blood (2012) 119:1407-17. doi:10.1182/blood-2011-06-363564

53. Accapezzato D, Visco V, Francavilla V, Molette C, Donato T, Paroli M, et al. Chloroquine enhances human CD8 $+\mathrm{T}$ cell responses against soluble antigens in vivo. J Exp Med (2005) 202:817-28. doi:10.1084/jem.20051106

54. Maecker HT, Ghanekar SA, Suni MA, He XS, Picker LJ, Maino VC. Factors affecting the efficiency of CD8+ T cell cross-priming with exogenous antigens. Jimmunol (2001) 166:7268-75.

55. Jin Y, Wai-kuo SJ, Berkhower I. Human T cell response to the surface antigen of hepatitis B virus (HBsAg). J Exp Med (1988) 168:293-306. doi:10.1084/jem. 168.1.293

56. Haniffa M, Shin A, Bigley V, McGovern N, Teo P, See P, et al. Human tissues contain CD141(hi) cross-presenting dendritic cells with functional homology to mouse CD103(+) nonlymphoid dendritic cells. Immunity (2012) 37:1-14. doi:10.1016/j.immuni.2012.04.012

57. Albert ML, Sauter B, Bhardwaj N. Dendritic cells acquire antigen from apoptotic cells and induce class I-restricted CTLs. Nature (1998) 392:86-9. doi:10.1038/32183

58. Larsson M, Fonteneau J-F, Somersan S, Sanders C, Bickham K, Thomas EK, et al. Efficiency of cross presentation of vaccinia virus-derived antigens by human dendritic cells. Eur J Immunol (2001) 31:3432-42. doi:10.1002/15214141(200112)31:12<3432::AID-IMMU3432>3.0.CO;2-R

59. Arrode G, Boccaccio C, Lulé J, Allart S, Moinard N, Abastado J, et al. Incoming human cytomegalovirus pp65 (UL83) contained in apoptotic infected fibroblasts is cross-presented to CD8 + T cells by dendritic cells. J Virol (2000) 74:10018-10024. doi:10.1128/JVI.74.21.10018-10024

60. Herr W, Ranieri E, Olson W, Zarour H, Gesualdo L, Storkus WJ. Mature dendritic cells pulsed with freeze - thaw cell lysates define an effective in vitro vaccine designed to elicit EBV-specific CD4+ and CD8+ T lymphocyte responses. Blood (2000) 96:1857-64.

61. Subklewe M, Paludan C, Tsang ML, Mahnke K, Steinman RM, Münz C. Dendritic cells cross-present latency gene products from Epstein-Barr virus - transformed B cells and expand tumor-reactive CD8+ killer T cells. J Exp Med (2001) 193:405-11. doi:10.1084/jem.193.3.405

62. Neijssen J, Herberts C, Drijfhout JW, Reits E, Janssen L, Neefjes J. Crosspresentation by intercellular peptide transfer through gap junctions. Nature (2005) 434:83-8. doi:10.1038/nature03290

63. Dolan BP, Gibbs KD, Ostrand-Rosenberg S. Dendritic cells cross-dressed with peptide MHC class I complexes prime CD8+ T cells. J Immunol (2006) 177:6018-24.

64. Qu C, Nguyen VA, Merad M, Randolph GJ. MHC class I/peptide transfer between dendritic cells overcomes poor cross-presentation by monocytederived APCs that engulf dying cells. J Immunol (2009) 182:3650-9. doi:10. 4049/jimmunol.0801532

65. Lozach P-Y, Burleigh L, Staropoli I, Navarro-Sanchez E, Harriague J, Virelizier J-L, et al. Dendritic cell-specific intercellular adhesion molecule 3-grabbing non-integrin (DC-SIGN)-mediated enhancement of dengue virus infection is independent of DC-SIGN internalization signals. J Biol Chem (2005) 280:23698-708. doi:10.1074/jbc.M504337200

66. de Jong MAWP, de Witte L, Bolmstedt A, van Kooyk Y, Geijtenbeek TBH. Dendritic cells mediate herpes simplex virus infection and transmission through the C-type lectin. J Gen Virol (2008) 89:2398-409. doi:10.1099/vir. 0.2008/003129-0

67. de Witte L, Abt M, Schneider-Schaulies S, van Kooyk Y, Geijtenbeek TBH. Measles virus targets DC-SIGN to enhance dendritic cell infection. J Virol (2006) 80:3477-86. doi:10.1128/JVI.80.7.3477-3486.2006

68. Hillaire MLB, Nieuwkoop NJ, Boon ACM, Rimmelzwaan GF. Binding of DCSIGN to the hemagglutinin of influenza A viruses supports virus replication in DC-SIGN expressing cells. PLoS One (2013) 8:e56164. doi:10.1371/journal. pone. 0056164 
69. Geijtenbeek TBH, Kwon DS, Torensma R, van Vliet SJ, van Duijnhoven GCF, Middel J, et al. DC-SIGN, a dendritic cell - specific HIV-1-binding protein that enhances transinfection of T cells. Cell (2000) 100:587-97. doi:10.1016/S0092-8674(00)80694-7

70. Jain P, Manuel SL, Khan ZK, Ahuja J, Quann K, Wigdahl B. DC-SIGN mediates cell-free infection and transmission of human T-cell lymphotropic virus type 1 by dendritic cells. J Virol (2009) 83:10908-21. doi:10.1128/JVI.01054-09

71. Unger WWJ, van Kooyk Y. "Dressed for success” C-type lectin receptors for the delivery of glyco-vaccines to dendritic cells. Curr Opin Immunol (2011) 23:131-7. doi:10.1016/j.coi.2010.11.011

72. Lambert AA, Gilbert C, Richard M, Beaulieu AD, Tremblay MJ. The C-type lectin surface receptor DCIR acts as a new attachment factor for HIV-1 in dendritic cells and contributes to trans- and cis-infection pathways. Blood (2008) 112:1299-307. doi:10.1182/blood-2008-01-136473

73. Op den Brouw ML, Binda RS, Geijtenbeek TBH, Janssen HLA, Woltman AM. The mannose receptor acts as hepatitis B virus surface antigen receptor mediating interaction with intrahepatic dendritic cells. Virology (2009) 393:84-90. doi:10.1016/j.virol.2009.07.015

74. de Witte L, Bobardt M, Chatterji U, Degeest G, David G, Geijtenbeek TBH, et al. Syndecan-3 is a dendritic cell-specific attachment receptor for HIV-1. Proc Natl Acad Sci U S A (2007) 104:19464-9. doi:10.1073/pnas.0703747104

75. de Witte L, Zoughlami Y, Aengeneyndt B, David G, van Kooyk Y, Gissmann $\mathrm{L}$, et al. Binding of human papilloma virus L1 virus-like particles to dendritic cells is mediated through heparan sulfates and induces immune activation. Immunobiology (2007) 212:679-91. doi:10.1016/j.imbio.2007.09.006

76. MacDonald KPA, Munster DJ, Clark GJ, Dzionek A, Schmitz J, Hart DNJ. Characterization of human blood dendritic cell subsets. Blood (2002) 100:4512-20. doi:10.1182/blood-2001-11-0097

77. Ebner S, Ehammer Z, Holzmann S, Schwingshackl P, Forstner M, Stoitzner $\mathrm{P}$, et al. Expression of C-type lectin receptors by subsets of dendritic cells in human skin. Int Immunol (2004) 16:877-87. doi:10.1093/intimm/dxh088

78. Bates EE, Fournier N, Garcia E, Valladeau J, Durand I, Pin JJ, et al. APCs express DCIR, a novel C-type lectin surface receptor containing an immunoreceptor tyrosine-based inhibitory motif. J Immunol (1999) 163:1973-83.

79. Lambotin M, Raghuraman S, Stoll-Keller F, Baumert TF, Barth H. A look behind closed doors: interaction of persistent viruses with dendritic cells. Nat Rev Microbiol (2010) 8:350-60. doi:10.1038/nrmicro2332

80. Eklöw C, Makrygiannakis D, Bäckdahl L, Padyukov L, Ulfgren A-K, Lorentzen JC, et al. Cellular distribution of the C-type II lectin dendritic cell immunoreceptor (DCIR) and its expression in the rheumatic joint: identification of a subpopulation of DCIR+ T cells. Ann Rheum Dis (2008) 67:1742-9. doi:10.1136/ard.2007.076976

81. Klechevsky E, Flamar A-L, Cao Y, Blanck J-P, Liu M, O’Bar A, et al. Crosspriming CD8+ T cells by targeting antigens to human dendritic cells through DCIR. Blood (2010) 116:1685-97. doi:10.1182/blood-2010-01-264960

82. Chatterjee B, Smed-sörensen A, Cohn L, Chalouni C, Vandlen R, Widger J, et al. Internalization and endosomal degradation of receptor-bound antigens regulate the efficiency of cross presentation by human dendritic cells. Blood (2012) 120:2011-20. doi:10.1182/blood-2012-01-402370

83. Turville SG, Cameron PU, Handley A, Lin G, Pöhlmann S, Doms RW, et al. Diversity of receptors binding HIV on dendritic cell subsets. Nat Immunol (2002) 3:975-83. doi:10.1038/ni841

84. Huysamen C, Willment JA, Dennehy KM, Brown GD. CLEC9A is a novel activation C-type lectin-like receptor expressed on BDCA3+ dendritic cells and a subset of monocytes. J Biol Chem (2008) 283:16693-701. doi:10.1074/jbc. M709923200

85. Flinsenberg TWH, Compeer EB, Koning D, Klein M, Amelung FJ, van Baarle $\mathrm{D}$, et al. Fc $\gamma$ receptor antigen targeting potentiates cross-presentation by human blood and lymphoid tissue BDCA-3+ dendritic cells. Blood (2012) 120:5163-72. doi:10.1182/blood-2012-06-434498

86. Tel J, van der Leun AM, Figdor CM, Torensma R, de Vries IJM. Harnessing human plasmacytoid dendritic cells as professional APCs. Cancer Immunol Immunother (2012) 61:1279-88. doi:10.1007/s00262-012-1210-Z

87. Donaghy H, Wilkinson J, Cunningham AL. HIV interactions with dendritic cells: has our focus been too narrow? J Leukoc Biol (2006) 80:1001-12. doi:10.1189/jlb.0306158

88. Lui G, Manches O, Angel J, Molens J-P, Chaperot L, Plumas J. Plasmacytoid dendritic cells capture and cross-present viral antigens from influenza-virus exposed cells. PLoS One (2009) 4:e7111. doi:10.1371/journal.pone.0007111
89. Crozat K, Guiton R, Contreras V, Feuillet V, Dutertre C-A, Ventre E, et al. The XC chemokine receptor 1 is a conserved selective marker of mammalian cells homologous to mouse CD8alpha+ dendritic cells. J Exp Med (2010) 207:1283-92. doi:10.1084/jem.20100223

90. Bachem A, Hartung E, Güttler S, Mora A, Zhou X, Hegemann A, et al. Expression of XCR1 characterizes the Batf3-dependent lineage of dendritic cells capable of antigen cross-presentation. Front Immunol (2012) 3:214 doi:10.3389/fimmu.2012.00214

91. Moris A, Nobile C, Buseyne F, Porrot F, Abastado J-P, Schwartz O. DC-SIGN promotes exogenous MHC-I-restricted HIV-1 antigen presentation. Blood (2004) 103:2648-54. doi:10.1182/blood-2003-07-2532

92. Tjomsland V, Elleg R, Che KF, Westmacott G, Hinkula J, Lifson JD, et al. Complement opsonization of HIV-1 results in a different intracellular processing pattern and enhanced MHC class I presentation by dendritic cells. Eur J Immunol (2013) 43:1-14. doi:10.1002/eji.201242935

93. Tacken PJ, Ginter W, Berod L, Cruz LJ, Joosten B, Sparwasser T, et al. Targeting DC-SIGN via its neck region leads to prolonged antigen residence in early endosomes, delayed lysosomal degradation, and cross-presentation. Blood (2011) 118:4111-9. doi:10.1182/blood-2011-04-346957

94. Schreibelt G, Klinkenberg LJJ, Cruz LJ, Tacken PJ, Tel J, Kreutz M, et al. The Ctype lectin receptor CLEC9A mediates antigen uptake and cross-presentation by human blood BDCA3+ myeloid dendritic cells. Blood (2012) 119:2284-92. doi:10.1182/blood-2011-08-373944

95. Celis E, Zurawski VR, Chang TW. Regulation of T-cell function by antibodies: enhancement of the response of human T-cell clones to hepatitis B surface antigen by antigen-specific monoclonal antibodies. Proc Natl Acad Sci U S A (1984) 81:6846-50. doi:10.1073/pnas.81.21.6846

96. Barth H, Schnober EK, Neumann-Haefelin C, Thumann C, Zeisel MB, Diepolder HM, et al. Scavenger receptor class B is required for hepatitis C virus uptake and cross-presentation by human dendritic cells. J Virol (2008) 82:3466-79. doi:10.1128/JVI.02478-07

97. Murshid A, Gong J, Calderwood SK. The role of heat shock proteins in antigen cross presentation. Front Immunol (2012) 3:63. doi:10.3389/fimmu.2012.00063

98. Burgdorf S, Schölz C, Kautz A, Tampé R, Kurts C. Spatial and mechanistic separation of cross-presentation and endogenous antigen presentation. Nat Immunol (2008) 9:558-66. doi:10.1038/ni.1601

99. Segura E, Villadangos JA. A modular and combinatorial view of the antigen cross-presentation pathway in dendritic cells. Traffic (2011) 12:1677-85. doi:10.1111/j.1600-0854.2011.01254.x

100. van Montfoort N, Camps MG, Khan S, Filippov DV, Weterings JJ, Griffith $\mathrm{JM}$, et al. Antigen storage compartments in mature dendritic cells facilitate prolonged cytotoxic T lymphocyte cross-priming capacity. Proc Natl Acad Sci U S A (2009) 106:6730-5. doi:10.1073/pnas.0900969106

101. Faure F, Mantegazza A, Sadaka C, Sedlik C, Jotereau F, Amigorena S. Longlasting cross-presentation of tumor antigen in human DC. Eur J Immunol (2009) 39:380-90. doi:10.1002/eji.200838669

102. Segura E, Durand M, Amigorena S. Similar antigen cross-presentation capacity and phagocytic functions in all freshly isolated human lymphoid organresident dendritic cells. J Exp Med (2013) 210:1035-47. doi:10.1084/jem. 20121103

103. Neefjes J, Sadaka C. Into the intracellular logistics of cross-presentation. Front Immunol (2012) 3:31. doi:10.3389/fimmu.2012.00031

104. Burgdorf S, Kautz A, Böhnert V, Knolle PA, Kurts C. Distinct pathways of antigen uptake and intracellular routing in CD4 and CD8 T cell activation. Science (2007) 316:612-6. doi:10.1126/science.1137971

105. Compeer EB, Flinsenberg TWH, van der Grein SG, Boes M. Antigen processing and remodeling of the endosomal pathway: requirements for antigen crosspresentation. Front Immunol (2012) 3:37. doi:10.3389/fimmu.2012.00037

106. Skehel JJ, Wiley DC. Receptor binding and membrane fusion in virus entry: the influenza hemagglutinin. Annu Rev Biochem (2000) 69:531-69. doi:10.1146/ annurev.biochem.69.1.531

107. Cohn L, Chatterjee B, Esselborn F, Smed-sörensen A, Nakamura N, Chalouni $\mathrm{C}$, et al. Antigen delivery to early endosomes eliminates the superiority of human blood BDCA3 + dendritic cells at cross presentation. J Exp Med (2013) 210:1049-63. doi:10.1084/jem.20121251

108. Albert ML, Pearce SF, Francisco LM, Sauter B, Roy P, Silverstein RL, et al. Immature dendritic cells phagocytose apoptotic cells via alphavbeta5 and CD36, and cross-present antigens to cytotoxic T lymphocytes. J Exp Med (1998) 188:1359-68. doi:10.1084/jem.188.7.1359 
109. Fonteneau JF, Kavanagh DG, Lirvall M, Sanders C, Cover TL, Bhardwaj N, et al. Characterization of the MHC class I cross-presentation pathway for cell-associated antigens by human dendritic cells. Blood (2003) 102:4448-55. doi:10.1182/blood-2003-06-1801

110. Stober D, Trobonjaca Z, Reimann J, Schirmbeck R. Dendritic cells pulsed with exogenous hepatitis B surface antigen particles efficiently present epitopes to MHC class I-restricted cytotoxic T cells. Eur J Immunol (2002) 32:1099-108. doi:10.1002/1521-4141(200204)32:4<1099::AID-IMMU1099>3.0.CO;2-8

111. Lakadamyali M, Rust MJ, Zhuang X. Ligands for clathrin-mediated endocytosis are differentially sorted into distinct populations of early endosomes. Cell (2006) 124:997-1009. doi:10.1016/j.cell.2005.12.038

112. Ludwig IS, Lekkerkerker AN, Depla E, Bosman F, Musters JP, Depraetere S, et al. Hepatitis C virus targets DC-SIGN and L-SIGN to escape lysosomal degradation. J Virol (2004) 78:8322-32. doi:10.1128/JVI.78.15.8322

113. Zehner M, Chasan AI, Schuette V, Embgenbroich M, Quast T, Kolanus W, et al. Mannose receptor polyubiquitination regulates endosomal recruitment of p97 and cytosolic antigen translocation for cross-presentation. Proc Natl Acad Sci U S A (2011) 108:9933-8. doi:10.1073/pnas.1102397108

114. Di Pucchio T, Chatterjee B, Smed-Sörensen A, Clayton S, Palazzo A, Montes $\mathrm{M}$, et al. Direct proteasome-independent cross-presentation of viral antigen by plasmacytoid dendritic cells on major histocompatibility complex class I. Nat Immunol (2008) 9:551-7. doi:10.1038/ni.1602

115. Ossendorp F, Fu N, Camps M, Granucci F, Gobin SJP, van den Elsen PJ, et al. Differential expression regulation of the alpha and beta subunits of the PA28 proteasome activator in mature dendritic cells. J Immunol (2005) 174: 7815-22.

116. Tel J, Sittig SP, Blom RAM, Luis J, Schreibelt G, Figdor CG, et al. Targeting uptake receptors on human plasmacytoid dendritic cells triggers antigen crosspresentation and robust type I IFN secretion. J Immunol (2013) 191:5005-12. doi:10.4049/jimmunol.1300787

117. Larsson M, Messmer D, Somersan S, Fonteneau J, Donahoe SM, Lee M, et al. Requirement of mature dendritic cells for efficient activation of influenza Aspecific memory CD8 + T cells. J Immunol (2000) 165:1182-90.

118. Tel J, Schreibelt G, Sittig SP, Mathan TSM, Buschow SI, Cruz LJ, et al. Human plasmacytoid dendritic cells efficiently cross-present exogenous Ags to CD8+ T cells despite lower Ag uptake than myeloid dendritic cell subsets. Blood (2013) 121:459-67. doi:10.1182/blood-2012-06-435644

119. Fonteneau J-F, Gilliet M, Larsson M, Dasilva I, Münz C, Liu Y-J, et al. Activation of influenza virus-specific CD4+ and CD8+ T cells: a new role for plasmacytoid dendritic cells in adaptive immunity. Blood (2003) 101:3520-6. doi:10.1182/blood-2002-10-3063

120. Woltman AM, Op den Brouw ML, Biesta PJ, Shi CC, Janssen HLA. Hepatitis $B$ virus lacks immune activating capacity, but actively inhibits plasmacytoid dendritic cell function. PLoS One (2011) 6:e15324. doi:10.1371/journal.pone. 0015324

121. Holm CK, Jensen SB, Jakobsen MR, Cheshenko N, Horan KA, Moeller HB, et al. Virus-cell fusion as a trigger of innate immunity dependent on the adaptor STING. Nat Immunol (2012) 13:737-43. doi:10.1038/ni.2350

122. Joffre O, Nolte MA, Spörri R, Reise Sousa C. Inflammatory signals in dendritic cell activation and the induction of adaptive immunity. Immunol Rev (2009) 227:234-47. doi:10.1111/j.1600-065X.2008.00718.x

123. Chen GY, Nuñez G. Sterile inflammation: sensing and reacting to damage. Nat Rev Immunol (2010) 10:826-37. doi:10.1038/nri2873

124. Arrode G, Boccaccio C, Abastado J, Davrinche C. Cross-presentation of human cytomegalovirus pp65 (UL83) to CD8+ T cells is regulated by virus-induced, soluble-mediator-dependent maturation of dendritic cells. J Virol (2002) 76:142-150. doi:10.1128/JVI.76.1.142

125. Ebihara T, Shingai M, Matsumoto M, Wakita T, Seya T. Hepatitis C virusinfected hepatocytes extrinsically modulate dendritic cell maturation to activate T cells and natural killer cells. Hepatology (2008) 48:48-58. doi:10. 1002/hep. 22337

126. Locher C, Conforti R, Aymeric L, Ma Y, Yamazaki T, Rusakiewicz S, et al. Desirable cell death during anticancer chemotherapy. Ann N Y Acad Sci (2010) 1209:99-108. doi:10.1111/j.1749-6632.2010.05763.x

127. Ahrens S, Zelenay S, Sancho D, Hanc P, Kjær S, Feest C, et al. F-Actin is an evolutionarily conserved damage-associated molecular pattern recognized by
DNGR-1, a receptor for dead cells. Immunity (2012) 36:625-45. doi:10.1016/j. immuni.2012.03.008

128. Mittag D, Proietto AI, Loudovaris T, Mannering SI, Vremec D, Shortman K, et al. Human dendritic cell subsets from spleen and blood are similar in phenotype and function but modified by donor health status. J Immunol (2011) 186:6207-17. doi:10.4049/jimmunol.1002632

129. Nizzoli G, Krietsch J, Weick A, Steinfelder S, Facciotti F, Gruarin P, et al. Human CD1c+ dendritic cells secrete high levels of IL-12 and potently prime cytotoxic T-cell responses. Blood (2013) 122:932-42. doi:10.1182/blood-2013-04495424

130. Frleta D, Yu CI, Klechevsky E, Flamar A-L, Zurawski G, Banchereau J, et al. Influenza virus and poly(I:C) inhibit MHC class I-restricted presentation of cell-associated antigens derived from infected dead cells captured by human dendritic cells. J Immunol (2009) 182:2766-76. doi:10.4049/jimmunol. 0801720

131. Lapenta C, Santini SM, Spada M, Donati S, Urbani F, Accapezzato D, et al. IFN-alpha-conditioned dendritic cells are highly efficient in inducing crosspriming CD8(+) T cells against exogenous viral antigens. Eur J Immunol (2006) 36:2046-60. doi:10.1002/eji.200535579

132. Grosjean I, Caux C, Bella C, Berger I, Wild F, Banchereau J, et al. Measles virus infects human dendritic cells and blocks their allostimulatory properties for CD4+ T cells. J Exp Med (1997) 186:801-12. doi:10.1084/jem.186.6.801

133. Samady L, Costigliola E, MacCormac L, McGrath Y, Cleverley S, Lilley CE, et al. Deletion of the virion host shutoff protein (vhs) from herpes simplex virus (HSV) relieves the viral block to dendritic cell activation: potential of vhs - HSV vectors for dendritic cell-mediated immunotherapy. J Virol (2003) 77:3768-76. doi:10.1128/JVI.77.6.3768

134. Moutaftsi M, Mehl AM, Borysiewicz LK, Tabi Z. Human cytomegalovirus inhibits maturation and impairs function of monocyte-derived dendritic cells. Blood (2002) 99:2913-21. doi:10.1182/blood.V99.8.2913

135. Liu B, Woltman AM, Janssen HLA, Boonstra A. Modulation of dendritic cell function by persistent viruses. J Leukoc Biol (2009) 85:205-14. doi:10.1189/jlb. 0408241

136. Woltman AM, Boonstra A, Janssen HLA. Dendritic cells in chronic viral hepatitis B and C: victims or guardian angels? Gut (2010) 59:115-25. doi:10.1136/ gut.2009.181040

137. Bachem A, Güttler S, Hartung E, Ebstein F, Schaefer M, Tannert A, et al. Superior antigen cross-presentation and XCR1 expression define human CD11c+CD141+ cells as homologues of mouse CD8+ dendritic cells. J Exp Med (2010) 207:1273-81. doi:10.1084/jem.20100348

138. Robbins SH, Walzer T, Dembélé D, Thibault C, Defays A, Bessou G, et al. Novel insights into the relationships between dendritic cell subsets in human and mouse revealed by genome-wide expression profiling. Genome Biol (2008) 9:R17. doi:10.1186/gb-2008-9-1-r17

139. Savina A, Peres A, Cebrian I, Carmo N, Moita C, Hacohen N, et al. The small GTPase Rac2 controls phagosomal alkalinization and antigen crosspresentation selectively in CD8(+) dendritic cells. Immunity (2009) 30:544-55. doi:10.1016/j.immuni.2009.01.013

140. Sancho D, Reis e Sousa C. Sensing of cell death by myeloid C-type lectin receptors. Curr Opin Immunol (2013) 25:46-52. doi:10.1016/j.coi.2012.12.007

141. Zelenay S, Keller AM, Whitney PG, Schraml BU, Deddouche S, Rogers NC, et al. The dendritic cell receptor DNGR-1 controls endocytic handling of necrotic cell antigens to favor cross-priming of CTLs in virus-infected mice. JClin Invest (2012) 122:1615-27. doi:10.1172/JCI60644

142. Hoeffel G, Ripoche A, Matheoud D, Nascimbeni M, Gannage M, Escriou N, et al. Antigen crosspresentation by human plasmacytoid dendritic cells. Immunity (2007) 27:481-92. doi:10.1016/j.immuni.2007.07.021

143. Segura E, Valladeau-Guilemond J, Donnadieu M-H, Sastre-Garau X, Soumelis V, Amigorena S. Characterization of resident and migratory dendritic cells in human lymph nodes. J Exp Med (2012) 209:653-60. doi:10.1084/jem. 20111457

144. Banchereau J, Zurawski S, Thompson-Snipes L, Blanck J-P, Clayton S, Munk A, et al. Immunoglobulin-like transcript receptors on human dermal CD14+ dendritic cells act as a CD8-antagonist to control cytotoxic T cell priming. Proc Natl Acad Sci U S A (2012) 109:18885-90. doi:10.1073/pnas. 1205785109 
145. Matsuo M, Nagata Y, Sato E, Atanackovic D, Valmori D, Chen Y-T, et al. IFNgamma enables cross-presentation of exogenous protein antigen in human Langerhans cells by potentiating maturation. Proc Natl Acad Sci U S A (2004) 101:14467-72. doi:10.1073/pnas.0405947101

146. Zhang Y, Liu Y, Moxley KM, Golden-Mason L, Hughes MG, Liu T, et al. Transduction of human T cells with a novel T-cell receptor confers anti-HCV reactivity. PLoS Pathog (2010) 6:e1001018. doi:10.1371/journal.ppat.1001018

147. Gehring AJ, Xue S-A, Ho ZZ, Teoh D, Ruedl C, Chia A, et al. Engineering virusspecific $T$ cells that target HBV infected hepatocytes and hepatocellular carcinoma cell lines. J Hepatol (2011) 55:103-10. doi:10.1016/j.jhep.2010.10.025

148. van der Burg SH, Arens R, Melief CJM. Immunotherapy for persistent viral infections and associated disease. Trends Immunol (2011) 32:97-103. doi:10.1016/j.it.2010.12.006

149. Tel J, Benitez-ribas D, Hoosemans S, Cambi A, Adema GJ, Figdor CG, et al. DEC-205 mediates antigen uptake and presentation by both resting and activated human plasmacytoid dendritic cells. Eur J Immunol (2011) 41:1014-23. doi:10.1002/eji.201040790

150. Kroczek RA, Henn V. The role of XCR1 and its ligand XCL1 in antigen crosspresentation by murine and human dendritic cells. Front Immunol (2012) 3:14. doi:10.3389/fimmu.2012.00014

151. Schuurhuis DH, Ioan-Facsinay A, Nagelkerken B, van Schip JJ, Sedlik C, Melief CJM, et al. Antigen-antibody immune complexes empower dendritic cells to efficiently prime specific CD8+ CTL responses in vivo. J Immunol (2002) 168:2240-6.
152. Zom GGP, Khan S, Filippov DV, Ossendorp F. TLR ligand-peptide conjugate vaccines: toward clinical application. Adv Immunol (2012) 114:177-201. doi:10.1016/B978-0-12-396548-6.00007-X

153. Gehring AJ, Haniffa M, Kennedy PT, Ho ZZ, Boni C, Shin A, et al. Mobilizing monocytes to cross-present circulating viral antigen in chronic infection. JClin Invest (2013) 123:3766-76. doi:10.1172/JCI66043

Conflict of Interest Statement: The authors declare that the research was conducted in the absence of any commercial or financial relationships that could be construed as a potential conflict of interest.

Received: 31 January 2014; paper pending published: 03 March 2014; accepted: 07 April 2014; published online: 23 April 2014.

Citation: van Montfoort N, van der Aa E and Woltman AM (2014) Understanding MHC class I presentation of viral antigens by human dendritic cells as a basis for rational design of therapeutic vaccines. Front. Immunol. 5:182. doi: 10.3389/fimmu.2014.00182 This article was submitted to Antigen Presenting Cell Biology, a section of the journal Frontiers in Immunology.

Copyright (C) 2014 van Montfoort, van der Aa and Woltman. This is an open-access article distributed under the terms of the Creative Commons Attribution License (CC $B Y)$. The use, distribution or reproduction in other forums is permitted, provided the original author(s) or licensor are credited and that the original publication in this journal is cited, in accordance with accepted academic practice. No use, distribution or reproduction is permitted which does not comply with these terms. 